日臨外会誌 $67(10), 2337-2340,2006$

症例

MEN1型に多房性胸腺囊胞と胸腺腫を合併した重症筋無力症の 1 例

国立病院機構札幌南病院外科

渡邅幹夫大坂喜彦菊地健福良撖宏

症例は40歳台の女性で多発性内分泌腫瘍症（MEN1型）に対する治療歴がある．嚥下 および首の挙上困難を主訴に近医を経て当院入院. 重症筋無力症, 胸腺腫と診断し拡大 胸腺摘出術を施行した，病理所見では多房性胸腺蕉胞と胸腺腫の合併で, 襄胞と胸腺腫 は近接するも明らかな連続はなく言胞部分は1991年にSuster とRosai が報告した所見 と一致，胸腺腫はWHO 分類て B2，正岡分類で I 期であった．本症例では MEN1型の 経過中他医にて胸部 CT が行われておりその所見から胸腺腫が先に発生し次いて胸腺豪 胞が発生したことも判明した．本症例につき報告する。

索引用語：多房性胸腺塞胞, 胸腺腫, 重症筋無力症

\section{はじめに}

多房性胸腺䨢胞（以下.NITC：multilocular thymic cyst）は1991年に Suster と Rosai が胸腺での炎症性変 化に起因し発生すると報告した後天性疾患である.今 回本疾患と胸腺腫を合併した重症筋無力症（以下 MG：myasthenia gravis）の 1 例を経験したので報告 する.また他疾患の既往があり，その治療中に撮影さ れた画像検查で縦隔の経過を確認できたので合わせて 報告する。

\section{症例}

患者：40歳台, 女性.

主訴：䓵下困難.

家族歴：兄に膵䑏と副甲状腺の手術歴，父方の従兄

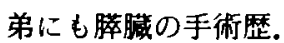

既往歴：多発性内分泌腫瘍症（MEN1型）にて2000 年 3 月脺体尾部切除術 (malignant islet tumor), 2000 年 5 月左副甲状腺切除術 (腺腫)，2004年 7 月右副甲状 腺切除術 (過形成).

現病歴：2004年 9 月ビールが飲み込みにくくなった ことに気付いた．その後仰向けでの首の挙上が困難と なり同年11月近医を受診, 脳 MRI では異常を認めず. エドロホニウム試験にて明らかに改善する鼻声, 顔面 筋と三角筋，頸部筋群の筋力低下があり，MG を疑わ

2006 年 5 月 22 日受付 2006 年 7 月 19 日採用

〈所属施設住所〉

テ061-2276 札幌市南区白川1814
れ当院神経内科入院となる. 電気生理学的検査, 理学 所見にて MGFA 分類III $\mathrm{b}$ の $\mathrm{MG}$ と診断, 合わせて画 像検査から胸腺腫の合併が疑われた。 Pyridostigmine bromide $180 \mathrm{mg}$ /日と prednisolone $10 \mathrm{mg}$ /日の投与て 症状の軽快を得たが本人の希望があり一旦退院，今回 手術目的で再入院となった。

入院時現症：身長 $158.1 \mathrm{~cm}$, 体重 $57.6 \mathrm{~kg}$, 血圧 $130 /$ $80 \mathrm{mmHg}$, 脈拍 $80 /$ 分. 眼瞼下垂・複視・德下困難・構 語障害などの神経症状を含め自覚症状はなし，右握力 $24.9 \mathrm{~kg}$, 左握力 $24.0 \mathrm{~kg}$, 頭部の臥位からの挙上維持可 能時間は31秒であった。

入院時検查：血液一般，生化学検査に異常を認めな かった．各腫境マーカーも正常範囲内であったが，抗 アセチルコリン受容体抗体（以下抗 AchR 抗体）が22 $\mathrm{nmol} / 1$ と異常值を示した. MEN1に関連する検查で は, 血清 $\mathrm{Ca}$, 副甲状腺ホルモン, 血糖値は正常範囲内 であったが，ガストリンが高值であった(表 1 )。呼吸 機能, 血液ガス分析は正常範囲内であった。

表 1

\begin{tabular}{|l|r|l|}
\hline 検查項目 & 結果 & 基準値 \\
\hline 抗 AchR 抗体 & $22 \mathrm{nmol} / \mathrm{L}$ & $(0.2 \mathrm{nmol} / 1$ 以下) \\
\hline $\mathrm{Ca}$ & $9.3 \mathrm{mg} / \mathrm{dl}$ & $(8.2-10.2 \mathrm{mg} / \mathrm{dl})$ \\
\hline FBS & $98 \mathrm{mg} / \mathrm{dl}$ & $(60-105 \mathrm{mg} / \mathrm{dl})$ \\
\hline $\mathrm{PTH}$-インタクト & $62 \mathrm{pg} / \mathrm{ml}$ & $(10-63 \mathrm{pg} / \mathrm{ml})$ \\
\hline ガストリン & $1.300 \mathrm{pg} / \mathrm{ml}$ & (負荷前 $200 \mathrm{pg} / \mathrm{ml}$ 以下) \\
\hline
\end{tabular}




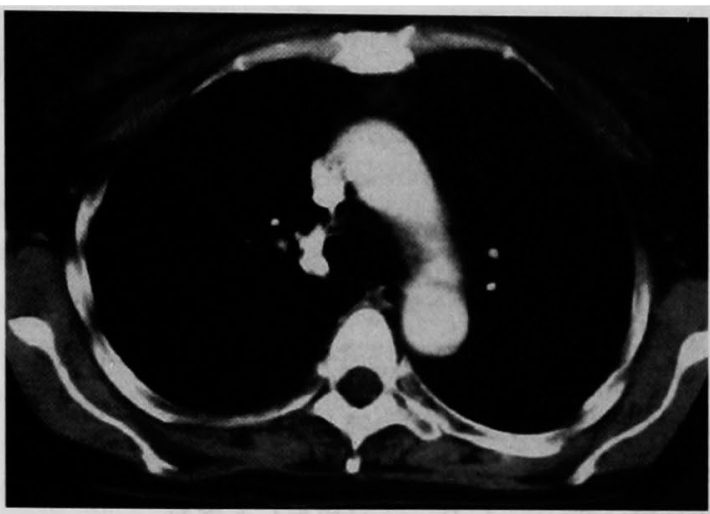

図 1 胸部造影 CT 画像：大動脈前面に内部構造不均一 の腫痛影を認める。

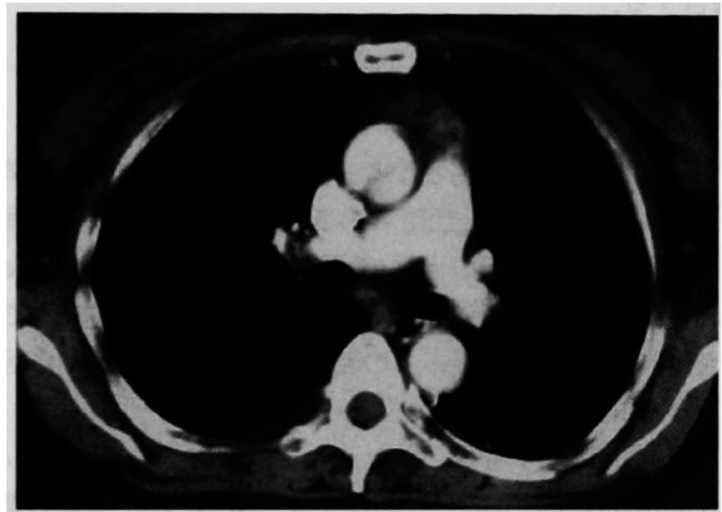

図 2 胸部造影 CT 画像：肺動脈起始部の心接して 腫留影を認める。

胸部造影 CT 検查：上行大動脈の前面と肺動脈根部 に接する類円形の内部構造やや不均一の腫瘤影を認め た図 1,2$)$.

$\mathrm{NG}$ ，不整形の胸腺腫の術前診断にて2005年 1 月手 術施行した. $1 \%$ propfol と suxamethonium chlorideにて全身麻酔を導入し, nitrous oxide $と$ sevoflurane $に$ て維持し，胸骨正中切刑て拉大胸腺摘出術 在施行した，前頸筋群周囲に㾾着がみられたが腫瘍の 心喜への浸潤はななった。切除組織量は107g，手術室 で気管内チューブを抜管し自発呼吸で病棟に戻った。

肉眼所見：胸腺左葉に $40145 \mathrm{~mm}$ 大の胸腺腫，これ に接しほほ中央に茶褐色の液体を内包した $40 \times 25 \mathrm{~mm}$ 大の多房性の毫胞か;存在していた（図 3 ）.

病理所見：胸腺腫の最大径々約 $35 \mathrm{~mm}, 1 \mathrm{HI}$ )分類 B2相当で厚い線維性結合組織で蕧われ被膜内への浸 潤は認められなかった，䉴胞部分は胸腺の脂肪組織内

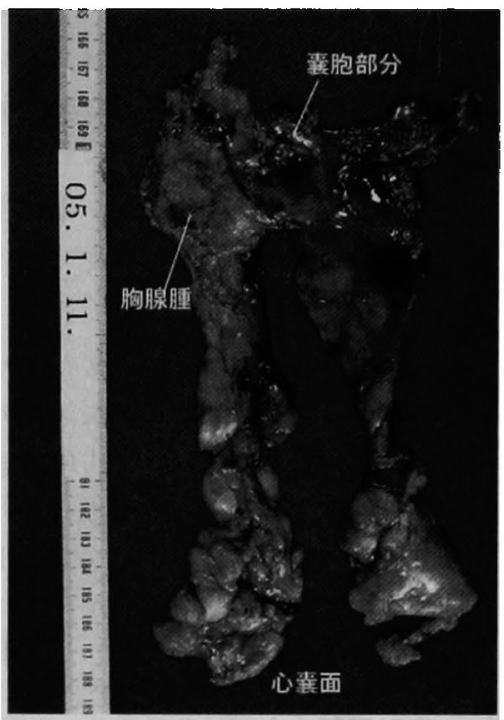

图 3 切除標本 (心罴面から撮影):胸腺 中央に萁胞部分，胸腺左葉内に胸腺腫 を認める。

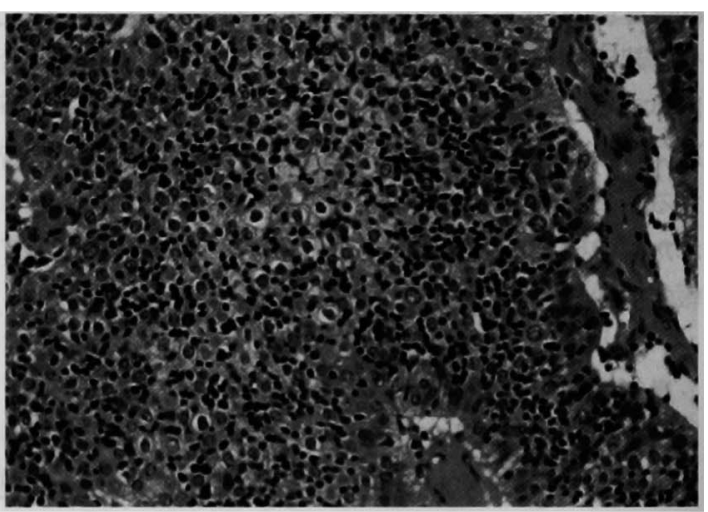

图 4 病理組織標本 $(\mathrm{HE}$ 染色 $\times 200)$ ：胸腺腫部分は卵 円形の腫瘍細胞とリンパ球を認める。WHO分類は Type B2.

に存在し，内面を一層〜数層の立方〜扁平上皮で覆わ れ，壁内および周囲に島状の Hassall 小体を含む胸腺 組織とリンパ球の集簇巣がみられた。豪胞壁および垂 胞間の組織には副甲状腺組織は認められず chromogranin A も陰性であった。衰胞壁には軽度の線維化を 認めるが，壁内には胸腺腫の組織は認められなかった

(図 4, 5).

術後経過は良好で川( 症状の増悪はなく術後28日 目にpyridostigmine bromide $180 \mathrm{mg} /$ 日 と prednisolone $20 \mathrm{mg}$ 隔日投与で自宅退院となった。 


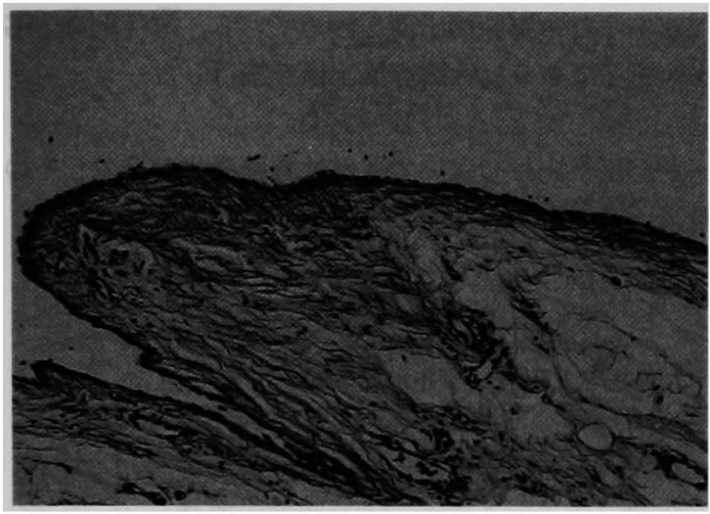

図 5 病理組織標本 $(\mathrm{HE}$ 染色 $\times 100)$ ：胸腺妻胞は一層 ～数層の立方〜扁平上皮て覆われている.

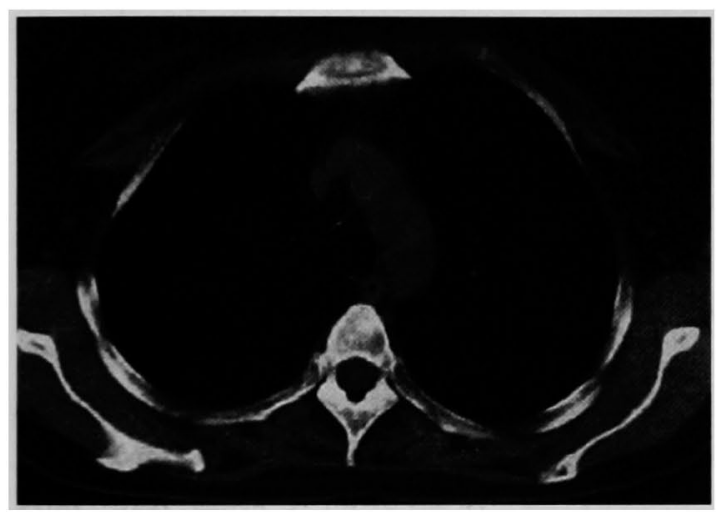

図 6 胸部単純 CT 画像：大動脈前面に腫瘤影は認めず.

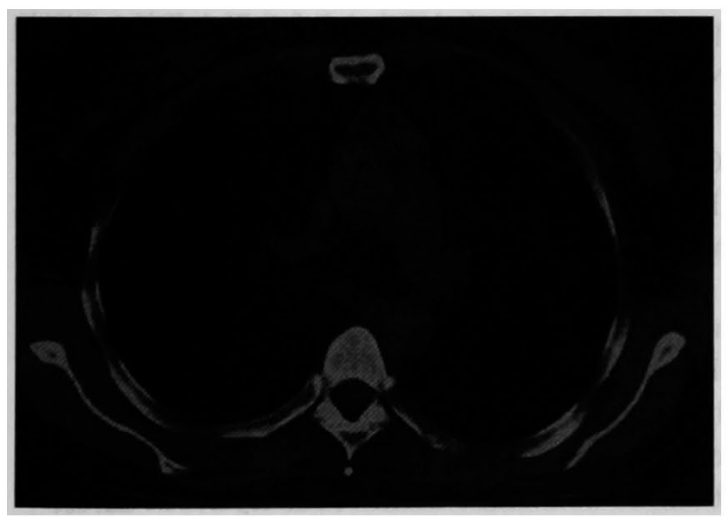

図 7 胸部単純 CT 画像：肺動脈起始部の心接して 腫慮影を認める。

\section{考 察}

1991年 Suster とRosai ${ }^{11}$ はTC の18例を検討し報 告した.この中で先天性の葆胞が単房性のことが多い

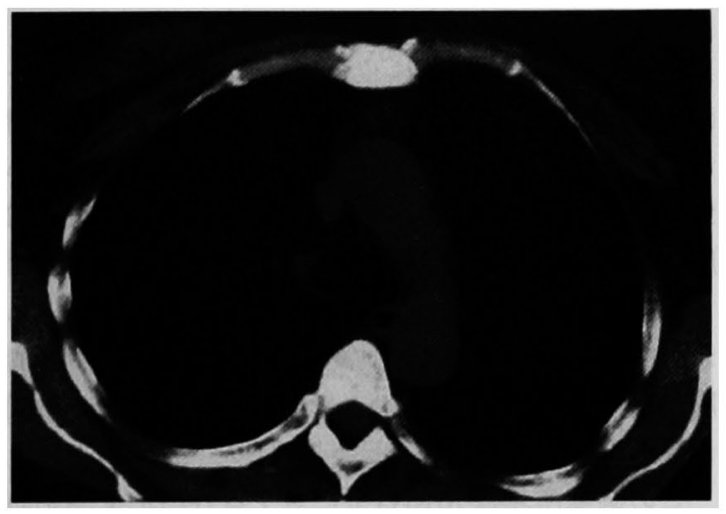

図 8 胸部単純 CT 画像：大動脈前面にも腫瘤影が確認 てる。

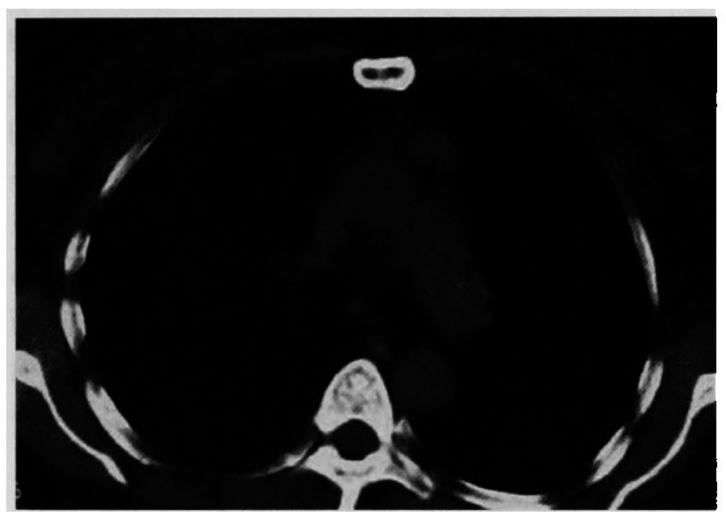

図 9 胸部単純 CT 画像：肺動脈起始部の心震に接して 腫溜影を認める。

のに対し多房性を示すこの病態変化には胸腺の炎症が 作用しており, 組織学的にも扁平, 円柱, 立方状の上 皮からなる毫胞壁内腔と嚄胞壁に散在する胸腺組織と ともに線維や血管の増殖を伴う急性, 慢性の炎症を認 めると指摘している，またこの内 2 例には罴胞壁内に 胸腺腫の合併があったことも記載されている。本邦で もMTCの報告は散見され，䟺胞壁に胸腺腫を併発し た症例 ${ }^{2}$, 胸腺過形成の合併例 ${ }^{3}$, 重症筋無力症の合併 例 ${ }^{4)}$, Sjögren 症候群に合併した症例の報告'がある.こ の報告の中で，奥村ら"は MG が顕在化する前の胸腺 内の変化が MTC 発生にもつながるのではないかと， Kondo ら ${ }^{5}$ は MTC の発生した背景となる自己免疫疾 患や腫瘍性病変の検索が必要であると述べている。来 た特殊な例として岡本ら ${ }^{6)}$ は気管支形成術の吻合部被 覆に用いた胸腺での MTC 発生例を報告し手術操作に 伴う炎症の波及が尧胞形成につながった可能性を指摘 
している.

MEN1型と胸腺腫の合併に関して Kojimaらつがそ の 1 例を報告しているが, 今回の症例も MEN1型に対 する治療歷がありその時々で胸部の CT を撮影してい た.これによると，2000年 1 月ては既に前絣隔に胸腺 腫を約 $2 \mathrm{~cm}$ 大の腫瘤影として 2 スライスで確認でき

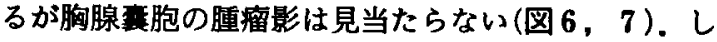
かし2003年 5 月ては胸腺腫より頭側の前縋隔に胸腺至 胞の隀瘤影が約 $2 \mathrm{~cm}$ 大 3 スライスで出現しこの間 に苳胞形成がなされたことが判明した（図 8，9）.

この画像所見はMEN1型に対する外科治療開始時 に既に胸腺腫を併発していたこと，MG 発症の 1 年 4 カ月前には既に MTC が出現していたことを示してい る.当科での1992年 6 月から2005年12月まての MGに 対する拡大胸腺摘出術は122例でりその内56例が胸 腺腫を合併していた。また同時期に自覚症状はない抗 AchR 抗体陽性の胸腺腫 6 例，抗体陰性の胸腺腫 2 例 に対して手術を施行してきた。多発性胸腺意胞を併発 していたのは今回の 1 例のみであり, 手術を施行した $\mathrm{MG}$ 全例の0.82\%に，また胸腺腫全68例の1.56\%にあ たり，合併須度は高いものではなかった，本症例の術 前画像診断は胸腺腫て, 切除組織で初めて多房性の严 胞部分が胸腺腫に接して存在することが判明したよう に，CTでの鏐別は困難であった。

治撩について Kondo ら5)は術前診断が難しいこと, 再発の可能性，真胞壁に胸腺上皮性腫瘍を合併するこ
とがあるため胸腺摘出術を勧めている。本症例は $\mathrm{MG}$ を合併しており拡大胸腺摘出術を施行した。 まとめ

胸腺腫が先行し次いで多房性胸腺至胞が発生しその 後に MG 症状が影在化した症例を経験した。

文献

1) Suster $S$, Rosai J : Multilocular thymic cyst : an acquired reactive process. Study of 18 cases. Am J Surg Pathol 15 : 388-398, 1991

2）小阪真二, 片倉浩理，金光尚樹地：胸腺蒦腫壁に 胸腺腫を合併した 1 症例。日呼外会誌 $14: 44-$ 48,2000

3）八柳英治, 草島勝之，竹澤周子：胸腺過形成を合 併した胸腺軎胞の 1 例. 日呼吸会誌 $41: 336$ 340,2003

4）奥村伸二，大田豊隆，藤岡宗宏 他：多房性胸腺童 胞を合併した重症筋無力症の 1 例. 日胸外会誌 43:917-921, 1995

5) Kondo K, Miyoshi T, Sakiyama S, et al: Multilocular thymic cyst associated with Sjo gren's syndrome. Ann Thorac Surg 72 : 13671369,2001

6）岡本 卓，横見瀬裕保，伤屋大煇他：有茎性心膜 周囲脂肪組織被覆を伴う気管支形成術後に発生し た多房性胸腺蕰胞。日呼外会誌 $17: 600-603$, 2003

7) Kojima $Y$, Ito $H$, Hasegawa $S$, et al : Resected invasive thymoma with multiple endocrine neoplasia type 1 . Jpn J THORACIC CAR. DIOVASC SURG $54: 171-173,2006$

\title{
A CASE OF MYASTHENIA GRAVIS ASSOCIATED WITH THYMOMA AND MULTILOCULAR THYMIC CYST IN MULTIPLE ENDOCRINE NEOPLASIA TYPE I SYNDROME
}

\author{
Mikio WATANABE, Yoshihiko OSAKA, Takeshi KIKUCHI \\ and Yoshihiro FUKURA \\ Department of Surgery, National Hospital Organization Sapporominami National Hospital
}

An about 40-year-old female patient who had been treated for multiple endocrine neoplasia (MEN) type 1 syndrome was referred to us because of difficulties in swallowing and in raising the neck. The patient was diagnosed as having myasthenia gravis with thymoma, and underwent extended thymectomy. Pathological examination revealed that thymoma was classified as type B2 according to WHO classification, and in Stage I according to Masaoka's classification. In addition, a multilocular cyst was demonstrated with clear separation from the thymoma. The histologic features of the cyst were compatible with those reported by Suster and Rosai, who suggested that it arises from processes of reactions to an acquired inflammatory change. Surveillance CT scans of the chest that had been sequentially taken for follow-up of MEN type 1 syndrome in another hospital suggested that the thymoma developed first and occurrence of the thymic cyst was afterward. 